\title{
Research Productivity and Publication Output: An Interdisciplinary Analysis
}

\section{Charles A. Schwartz}

\begin{abstract}
Although research productivity of librarians has been investigated for several decades, some fundamental problems of measurement and analysis have endured. This paper compares productivity patterns in library science with those in other fields and explains why such plausible factors as intellectual traits, educational experience, institutional support, and available time are not useful for understanding variation in scholarly output. The final part of the paper presents an overview of findings, examines certain myths that have dominated discussions in the library field, and suggests a different approach for future research.
\end{abstract}

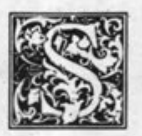

tudy of research productivity has attracted growing attention in the library field for more than fifty years and especially since issues of academic tenure have come to the fore. From precursory reports done at the University of Chicago in the 1930s to surveys of the literature in the 1980s, investigations have generally focused on such plausible productivity factors as having a Ph.D., institutional support, and available time..$^{1,2}$ Some fundamental problems, however, have deterred understanding in this area.

First, the literature offers few clues as to how analysis of productivity factors for librarians relates to that for social scientists as a whole. Moreover, the diversity of institutional contexts in the library field has obscured any continuity in the consideration of such factors.

This lack of systematic analysis also results from the common practice of considering all publications in library science to have equal research content or scholarly value. The prevalence of that simplifying assumption may stem from a desire to bypass the question of what exactly constitutes a piece of research, as well as from a need to keep investigations within manageable bounds. Whatever the actual reasons, the fact remains that hardly any reliable figures on research productivity of librarians exist. For example, Charles McClure and Ann Bishop, in a survey of productivity reports in the library field, list an assortment of largely unrelated findings with a claim that further review is not feasible: "Existing reports are rarely longitudinal, nor do they present data in a form comparable with earlier studies or make enlightening comparisons with studies in other disciplines." ${ }^{3}$

The analysis of research productivity set forth here is developed in six parts. Part one compares productivity patterns in the library field with those in the scholarly system as a whole. A consistent picture across all fields is that of a highly stratified system, in which a small pro-

Charles A. Schwartz is Social Sciences Librarian at the Fondren Library, Rice University, Houston, Texas 77251-1892. The author wishes to thank Robert Boice, David Kaser, Charles Martell, Charles R. $\mathrm{McCl}$ ure, and Herbert S. White for their helpful comments on an earlier draft of this paper. 
portion of participants produces much of the literature while the majority of Ph.D.s publish little or nothing in their lifetimes. Investigations of this wide variation in productivity traditionally have focused on such plausible factors as intellectual traits, educational experience, institutional support, and available time. These factors are examined in the next four parts of the paper. None of them, not even having a Ph.D., is generally effective. After several decades of research, some of it involving comparative analysis of thousands of academic careers, social scientists simply have failed to come up with a reliable model of productivity factors.

The last part of the paper presents an overview suggesting that any fairly stable propensity to do research seems to depend on a "sacred spark" of achievement needs, the cumulative advantage of early performance, and continuing socialization. Certain myths about research productivity are examined, and a different approach for future analysis is suggested.

\section{PRODUCTIVITY PATTERNS}

Two widely cited reports on research productivity suggest an average publication output of one article per year for librarians with Ph.D.s. ${ }^{4}$ What seems to have escaped general notice, however, are all the caveats and qualifications the authors of those two reports attached to their findings. Masse Bloomfield cautioned that his productivity rate was based simply on author listings for publications of any kind in the Library Literature index and that it was highly inflated by the output of some extremely prolific writers who received their Ph.D.s in the early 1960 s. $^{5}$

As with quantity, so with quality. Jana Varlejs and Prudence Dalrymple observed that fewer than 20 percent of the publications they counted were included in more than one of the three library science literature indexes. This finding indicated that the great majority of publications tend to be on the fringes of the field-outside the core of refereed, research-oriented national journals. ${ }^{6}$

Indeed, virtually all writers on this subject point out that most listings in library science indexes refer to opinion pieces published in local or institutional organs. ${ }^{7}$ More specifically, in a random sample Susan Bonzi found that 60 percent of the papers listed in Library Literature contain no references; and Christine Korytnyk found in another random sample that only a third of the publications in Library Literature are published in refereed journals. ${ }^{8,9}$ Also, Robert Hayes found that the majority of listings in the Social Sciences Citation Index for prolific writers in the library field are for book reviews by them, rather than for articles of any type. ${ }^{10}$ Even to rely on the use of references as an indicator of research quality is problematic; literature reviews of citation analyses reveal that roughly half of the references in core library journals tend to be irrelevant, not used to support any particular point. ${ }^{11}$

Recently, John Budd and Charles Seavey published an authorship study that provides, for the first time, multiyear data. They recorded the authors and institutional affiliations of 1,656 fulllength articles published in thirty-six library and information science journals from 1983 through 1987. Not all of those journals are scholarly or refereed, but their study comes closest to gauging research productivity in the field. Of a total 1,373 authors, 1,027 (75 percent) published only one article in the five-year period, and only 128 ( 9 percent) published more than two articles. Budd and Seavey suggested that insufficient institutional support might be responsible for such low productivity. ${ }^{12}$

Perspective may be gained by reviewing productivity patterns in other fields. Such a review requires some caution, given the variety of scholarly norms, refereeing processes, publishing outlets, and conceptions of what constitutes a piece of research. Indeed, the "wisdom of treating each discipline... separately" has been recognized for decades. ${ }^{13}$ The review presented here is meant simply to serve as a "reality check" of the broadest sort.

The publish-or-perish standard that supposedly governs American higher education actually applies to only a small 
band of elite institutions. Every study shows that most academics publish very little. This general pattern was first recognized in the mid-1950s when Paul Lazarsfeld and Wagner Thielens found that fewer than half of 2,451 social scientists had published more than three articles in their careers. ${ }^{14}$ In the early 1960 s, Nicholas Babchuk and Alan Bates found a corollary pattern: only a small proportion of academics publish much. In their sample of 262 sociologists holding Ph.D.s for at least ten years, Babchuk and Bates found that 36 percent had published no articles, 31 percent had one to three articles, 12 percent had four or five articles, 12 percent had six to nine articles, and the top 10 percent had ten to sixty articles. ${ }^{15}$

\section{The publish-or-perish standard that} supposedly governs American higher education actually applies to only a small band of elite institutions.

During the heyday of productivity studies in the late 1960s and early 1970s, two large-scale interdisciplinary studies were undertaken. The 1969 National Surveys of Higher Education, sponsored by the Carnegie Commission, found that more than half of 27,000 faculty members had not done any research during the preceding two years, while only 3 percent had published ten or more articles in that period. The diversity of participation in publishing was even more striking among different fields, ranging from 91 percent for biologists in elite universities to 9 percent for business faculty in junior colleges. The rate of participation for a category of practitioner fields that included library science ranged from 67 percent in elite universities to 13 percent in junior colleges. ${ }^{16}$

The other large-scale study was the 1972 American Council on Education survey of 17,399 faculty members at universities and four-year colleges. Briefly sketched, this survey reported lifetime mean averages for article productivity to be about thirteen in the natural sciences, nine in the social sciences, and six in the humanities. ${ }^{17}$ A smaller study in 1975 of lifetime research productivity, by Everett Ladd and Seymour Lipset, showed that only 4 percent of academics forty-five to fifty-four years of age were actively interested in research, another 21 percent did some research but leaned toward teaching, 50 percent published rarely, and the remaining 25 percent had published nothing in their careers. ${ }^{18}$

In the late 1970s, productivity studies in the library field began to gain momentum. Outside the field, however, this type of investigation had run its course as interests shifted to other areas, such as graduate school ratings and general surveys of advances in the social sciences. ${ }^{19,20}$

The essential point of these studies for our purposes is twofold: (a) the great majority of academics do surprisingly little research; and (b) when one counts all publications of librarians as being equal, measures of their scholarly output are overblown because of the various factors noted above that mitigate against any assumption that such output embodies comparable research value. Crossdisciplinary analysis of library science productivity with that of other fields, to any greater degree, becomes somewhat meaningless. For instance, in the American Council on Education survey library scientists are vaguely comparable to business and fine arts faculty members at the junior college level in the sense that only 10 percent of such individuals had published at least one article within the two years preceding the survey. ${ }^{21}$

\section{INTELLECTUAL TRAITS}

Psychologists have delineated a set of core intellectual traits of productive and creative individuals across a broad range of endeavors, including literature, art, music, and science. Such individuals are said, for example, to handle problems with much more ego strength, reflection, persistence, tolerance for ambiguity, and attraction to complexity than their colleagues. ${ }^{2}$ In a similar vein, sociologists have described the work habits of eminent scholars in terms of a "sacred spark" productivity thesis, 
which holds that an inner drive compels some scholars to do research, even in the absence of rewards..$^{23}$

\section{Sociologists have described the work habits of eminent scholars in terms of a "sacred spark" productivity thesis.}

The overwhelming limitation of this approach, however, is that generally reliable ways of developing intellectual traits are unknown. It does little good to espouse such traits when no one can teach them effectively. Likewise, no one can explain background or behavioral factors that account for the "sacred spark" phenomenon. Accordingly, investigation in this area was abandoned by most scholars in the 1970 s, leaving a vacuum in the literature that has been filled with how-to books on creativity written by nonspecialists for the popular press. ${ }^{24}$

\section{EDUCATIONAL EXPERIENCE}

Although there is an intuitive symmetry between research productivity and the doctorate, the actual relationship is full of incongruities. Consider the plausible factors of (a) predoctoral work experience and (b) quality of graduate training. In the library field, reports on predoctoral experience as a factor of postdoctoral productivity are contradictory. Kathleen Garland and Galen Rike, in a study of 168 library science faculty members, posited a direct relationship: those who earn Ph.D.s after many years of practice in the field are likely to publish the most..$^{25}$ Other writers, however, have described an inverse relationship between predoctoral experience and subsequent productivity. Nancy Lane, in a 1975 dissertation, found that prolific writers tend to have fewer years of practice; and Pauline Wilson conjectured that extensive library experience, being pragmatic rather than research oriented, may work against the internalization of scholarly norms in a doctoral program. ${ }^{26}$

A third line of investigation holds that no discernible relationship between pre- degree experience and postdoctoral productivity exists. Herbert White and Karen Momenee, in a 1978 survey of 403 library Ph.D.s, found that neither professional practice nor publication activity leading up to the doctorate appears to be associated with later productivity:

This would appear to be a sharp indictment ... of the quality of present doctoral programs: in their selection criteria, in communicating to students the conditions and responsibilities of what the terminal degree means and requires, in the school's treatment of research, and in the acceptance of lesser standards in the undertaking of research leading to the dissertation. ${ }^{27}$

In effect, White and Momenee showed that librarians, by and large, go through $\mathrm{Ph}$.D. training without becoming socialized to scholarly norms in the process. ${ }^{28}$

Investigations in social science fields, however, have discounted quality of doctoral programs as a signficant factor in later research productivity. For example, Frank Clemente and Richard Sturgis, in a series of analyses of early career determinants of Ph.D.s in sociology, found that quality of doctoral programs accounts for less than 10 percent of the variation of postdoctoral research output. To reassess this startling conclusion, they tested the hypothesis that a Ph.D. from a top-quality department could be a "necessary but not sufficient condition" of high productivity by using more sophisticated statistical techniques than linear regression. That test supported their original findings, which were based on the publication records of 2,205 academics over a thirty-year period. ${ }^{29}$

Indeed, the American Council on Education survey described earlier also found that among faculty in the social sciences and humanities, such factors as quality of doctoral programs, tenure, teaching load, grants and fellowships, and even possession of the Ph.D. bear only weak relationships to research and publication..$^{30}$ However, the survey did find other factors to be generally associated with research productivity, including years of post-doctoral experience, number of journals regularly read, 
weekly time at research, and quality of employing institution.

Some additional significant factors were found to have more complex interactions. For example, teaching load has a salient effect only for members of the humanities, and then its effect is partially positive-the greater the time spent teaching, the greater the productivity for publishing books, though not articles. Also, while academic rank and productivity are highly correlated, the survey (not being longitudinal) could not determine their causal directionwhether prolific writers simply advance in rank and then perhaps produce less or whether full professors and deans continue to publish at a high rate. ${ }^{31}$

\section{INSTITUTIONAL SUPPORT}

What is known in any systematic way about institutional support for research activity of librarians indicates a grossly ineffective professional development system. First, although three out of four academic libraries provide faculty or academic status of some sort, only a few require librarians to publish. For example, about 15 percent (ten university libraries) of Association of Research Libraries member institutions appear to have that requirement. ${ }^{32}$ In other academic institutions, criteria for librarians are substantially modified to maintain job performance as the key or sole consideration. ${ }^{33}$ Indeed, Budd and Seavey found that, although 60 percent of a sample group of institutions either require or strongly encourage publication for promotion, there is a striking "disparity between the rhetoric of the requirements and the performance exhibited by librarians at those institutions." ${ }^{34}$

Second, publishing activity by librarians-even where required by universities-is not generally evaluated for research content or quality. Rather, all types of nonrefereed items (conference papers, book reviews, in-house pieces, and so forth) are acceptable. ${ }^{35}$ Third, faculty status does not promote publishing productivity, let alone research work. In an analysis of authors and their institutional promotion and tenure systems,
Paula Watson found that "there is not a marked difference in productivity between those who must meet true faculty standards .... and those who do not." ${ }^{36}$ Moreover, an analysis by Karen Smith and Gemma DeVinney of 530 tenured librarians at thirty-three large academic libraries showed that about 47 percent of the librarians had no publications at the time they received tenure, 19 percent had just one publication, and 34 percent had two or more. ${ }^{37}$

Finally, publishing activity by librarians is not usually supported, even where required. While there is very little consistency in faculty status systems from institution to institution, professional development funds appear to be reserved mainly for conference expenses. ${ }^{38}$ Additionally, Nancy Emmick calculated from a study of professional development funding in 367 libraries that most of them grant somewhere between 1 and 5 percent of a librarian's time for all forms of professional development-at most, two hours a week. ${ }^{39}$

\section{AVAILABLE TIME}

The relationship between research productivity and available time has a couple of troublesome characteristics. First, investigations of this relationship across various fields do not generalize well-that is, they do not provide enlightening perspectives beyond the grasp of ordinary knowledge. One group of writers, for example, suggests that productivity is a function of time. Within this group, however, writers disagree about whether large blocks of uninterrupted sessions at home or brief stints during the workday are more productive. ${ }^{40,41}$

Another group takes the opposing position that productivity is not a function of time; however, individual explanations differ as well. Most writers within this latter group believe that "everyone has sufficient time, though some have more than others," whereas others point out that "there is surely a factor of simple energy level that allows people who are active in one area [teaching or administration] to be active in other areas [re- 
search and publishing] beyond the average." 42,43

Whatever the bases of adherence to any of these positions, there is no logical basis for their being ranged against each other. Generalizations about productivity being a function of time can be tempered by considering their relationship as a curvilinear one, with the lowest levels of productivity being associated with either very large or very small proportions of time spent on research. ${ }^{44}$

Generalizations about productivity not being a function of time can also be tempered by considering the need for a regimen of a sort, writing regularly without undue regard for inspiration or convenience. For example, Aaron Wildavsky begins his book on scholarly writing by emphasizing the "importance of habit and rhythm: Try to work in the same place, at the same time, and in the same way .... so that body and mind expect to be called on and will respond." 45

Robert Boice has written widely on clinical treatments for writer's block based on a regimen of brief (thirty- to sixty-minute) daily writing sessions. ${ }^{46}$ As Boice points out, such an approach runs counter to conventional views of librarians and academics, who tend to believe that they need thirty minutes just to warm up. He describes such initial resistance at a writing productivity workshop (which was eventually successful):

Both groups [librarians and faculty members] seemed to have discretionary time that could have been devoted to scholarship. When asked about this possibility, almost every participant gave the same answer: their occasional breaks in an otherwise busy schedule were not sufficient for scholarship. Writing, they pointed out in almost complete agreement, requires large blocks of uninterrupted time. Thirty-minute blocks were too short. ${ }^{47}$ Basic realities of the library professionstructured schedules, the view that scholarship is a personal indulgence, and an overriding concern for patron serviceengender resistance to the notion of a writing regimen, however brief, during the workday.

\section{CONCLUSIONS}

The main conclusions of this paper, covering productivity factors and output patterns of scholarly research, stand in sharp contrast to two myths that have dominated discussions in the library field.

Myth \#1: The Ph.D. degree is a significant factor of research productivity; thus, when the numbers of doctorates reach a "critical mass," library science will take off in terms of aggregate scholarly progress.

On the contrary, the American Council on Education's large-scale survey concluded:

"It is curious that despite the vaunted role of the Ph.D. degree as the essential academic, scholarly, and scientific credential, when other determinants are controlled, its possession seems to confer no added increment to article productivity." 48

There is simply no evidence that possession of the Ph.D. accounts for any measurable part of variation in publication output, either in library science or in the scholarly system as a whole.

Nor is there support for the so-called "critical mass" expectation, which suggests that scholarly progress in the library field depends on the sheer number of Ph.D.s and the volume of their research activity. It is true that the growth of library science doctorates has been exponential: the cumulative total doubled in the late 1950s, doubled again in the late 1960s, again in the mid-1970s, and again in the early 1980 s - to about $1,000 .^{49}$ Yet the average productivity rate for Ph.D.s in the library field has actually declined-and in roughly proportional terms. According to Bloomfield's study, those who earned their degrees after the mid-1960s tend to publish at one-half to one-quarter the rate of the earlier generation of Ph.D.s.

Only part of this large decline can be attributed to the extremely high productivity of that earlier generation. Moreover, in writing about those early prolific Ph.D.s, David Kaser noted that, while they made up the leadership of the 
nation's largest academic libraries during the 1960 s, very few of them published real research work:

All of these directors had been, in their doctoral experience, imbued with the rigor of scholarly method; yet, . . . with the exception of one or two, virtually none of them pursued scholarly research in their later lives. Virtually all of them remained prolific authors. . . . but almost-none of them sustained in their postdoctoral careers what could be called, even with generosity, even a modest regimen of the research to which they were trained. ${ }^{50}$ Overall, the Ph.D. has become an increasingly common factor in research settings, but its impact has been greatly diminished or entirely muted in many of them.

Myth \#2: More large-scale statistical studies are necessary to determine general productivity factors and output patterns of research activity.

Everyone is in favor of better data and more analyses on virtually any topic, yet any such assumption about research productivity is misleading. It should make us pause when social scientists are unable to come up with anything that resembles a general explanation of scholarly output, one identifying significant factors within researchers' control. Any fairly stable propensity to do research somehow depends on a "sacred spark" of achievement needs, the cumulative advantage of early performance, and continuing socialization (mostly by working in a large university that recognizes research activity). Beyond that framework, no one really knows what to say; in the main, this field of inquiry has run its course, and most social scientists have abandoned it.

This lack of study is not to suggest a closure of inquiry, but rather that future investigation might well offer a shift in approach and focus. As discussed, the traditional approach-publication counts based on literature indexes - is wholly inadequate for measuring and analyzing research productivity in the library field. (That approach, of course, is based on the principle of expediency: any attempt to establish criteria of what is and is not a piece of research is persnickety in theory and time-consuming in practice.)

Moreover, much of what we would like to know of a practical nature, such as the potential for in-house research development programs, is context dependent and not at all likely to show up in aggregate statistics. One solution might be to take a more interpretive approach in which productivity is investigated in the context of specific institutional surroundings. The aim of inquiry would thus shift from discovering general "laws" of research productivity, to understanding particular cases of effective factors in particular settings. ${ }^{51}$

There is simply no evidence that possession of the Ph.D. accounts for any measurable part of variation in publication output, either in library science or in the scholarly system as a whole.

Consider as an illustration the issue of whether greater institutional support of research activity would be effective in the library field. Funding is so negligible and released time so scarce that one wonders whether this issue has been put to a real test. The literature on institutional support as a factor of research productivity of academics is mixed but helpful.

On the one hand, such support is not a significant factor for academics in the aggregate. As a general "law," people in any field who do little or no scholarly work do not tend to change course in response to the publish-or-perish standard, more benign forms of academic status, reduced teaching loads, or the like. Early performance is strongly associated with continued productivity in later years. Correspondingly, prolonged procrastination in research activity (beyond normal post dissertation paralysis) is likely to last a career. Late bloomers in the scholarly system are a rarity. ${ }^{52}$

On the other hand, colleague support appears to be especially relevant for librarians. Yoram Neumann and Edith 
Finaly-Neumann, in a comparative study of 380 faculty members drawn from certain sciences (physics and electrical engineering) and social sciences (sociology and education), tested the relative significance of colleague support for publication output in those domains. ${ }^{53}$ The study showed that such support is rather influential in the sciences (accounting for 47 percent of publication output variance in physics, 26 percent in electrical engineering), but quite weak in the social sciences (accounting for 15 percent of output variation in sociology, 12 percent in education). Other studies bear out this general finding. ${ }^{54}$

\section{Colleague support appears to be especially relevant for librarians.}

The essential reason for this difference in significance of colleague support between the sciences and the social sciences has a positive bearing on prospects for research collaboration in the library field. In the sciences, research can be highly collaborative within a department because colleagues have a common work environment-they share the same technology and much professional knowledge. In this kind of environment, ample opportunity for informal socialization, seminars, and other mechanisms exists to facilitate colleague support and feedback.

In the social sciences, by contrast, much less opportunity for collaborative research exists within a department because faculty hiring tends to maximize intellectual diversity as a means of ensuring instructional coverage of broad disciplines. In that kind of environment, lacking shared technology and subject expertise, institutional support is more people oriented than task oriented. The Neumanns observed that increases in pub- lication output may depend on department chairpersons setting helpful goals for new faculty members as a means of socializing them to scholarly norms.

The traditional approach ... is wholly inadequate for measuring and analyzing research productivity in the library field.

In the library field, both task and people orientations appear to be prospective factors of research productivity at the institutional level. A task orientation, based on shared expertise, would derive from librarians' knowledge of in-house technology and service functions. A people orientation, with its emphasis on goal setting and other forms of mentoring, would seem useful for reducing the role ambiguity of librarians who are motivated to do research but who perceive weak institutional support and performance recognition.

Overall, a set of four factors might inform future studies of research productivity in the library field: early socialization (in the first few years after graduate training); goal setting (to reduce role ambiguity); institutional support (e.g., project funding, released time, and performance recognition); and colleague support (e.g., collaborative efforts and informal seminars).

Finally, the great variation that exists among academics with respect to research productivity has not been recognized in the library field. Rather, the prevailing view has been that librarians are particularly negligent when it comes to publishing. Broader awareness of actual productivity patterns in the scholarly system, as described in this paper, should enable us to put this matter into better perspective.

\section{REFERENCES AND NOTES}

1. For a survey of the early library science and social science literature, see Nancy Diane Lane, "Characteristics Related to Productivity among Doctoral Graduate Students in Librarianship" (Ph.D. diss., Univ. of California-Berkeley, 1975), p.10-19. 
2. For recent surveys, see Charles R. McClure and Ann Bishop, "The Status of Research in Library/Information Science: Guarded Optimism," College \& Research Libraries 50:127-43 (Mar. 1989); and Kee DeBoer and Wendy Culotta, "The Academic Librarian and Faculty Status in the 1980s: A Survey of the Literature," College \& Research Libraries 48:215-23 (May 1987).

3. McClure and Bishop, "The Status of Research," p.128.

4. Masse Bloomfield, "A Quantitative Study of the Publishing Characteristics of Librarians," Drexel Library Quarterly 15:24-40 (July 1979); and Jana Varlejs and Prudence Dalrymple, "Publication Output of Library and Information Science Faculty," Journal of Education for Library and Information Science 27:71-89 (Fall 1986).

5. Bloomfield, "A Quantitative Study," p.27-28.

6. Varlejs and Dalrymple, "Publication Output," p.75.

7. See Lloyd J. Houser, "Dissertation Review," Library Research 2:269-73 (1980-81) on Bluma C. Peritz's, "Research in Library Science as Reflected in the Core Journals of the Profession: Research Productivity A Quantitive Study (1970-1975)" (Ph.D. diss., Univ. of California-Berkeley, 1977), published in summary form in Library Research 2:251-68 (1980-81).

8. Susan Bonzi, "Characteristics of a Literature as Predictors of Relatedness between Cited and Citing Works," Journal of the American Society for Information Science 33:211 (July 1982).

9. Christine A. Korytnyk, "Comparison of the Publishing Patterns between Men and Women Ph.D.s in Librarianship," Library Quarterly 58:63 (Jan. 1988).

10. Robert M. Hayes, "Citation Statistics as a Measure of Faculty Research Productivity," Journal of Education for Librarianship 23:158 (Winter 1983).

11. Donald A. Windsor and Diane M. Windsor, "Citation of the Literature by Information Scientists in Their Own Publications," Journal of the American Society for Information Science 24:377-81 (Sept.-Oct. 1973); and Bonzi, "Characteristics of a Literature," p.20912.

12. John Budd and Charles Seavey, "Characteristics of Journal Authorship," College \& Research Libraries 51:463-70 (Sept. 1990).

13. Bernard N. Meltzer, "The Productivity of Social Scientists," The American Journal of Sociology 55:29 (July 1949).

14. Paul F. Lazarsfeld and Wagner Thielens, Jr., The Academic Mind (Glencoe, Ill.: Free Pr., 1958), p.397-98.

15. Nicholas Babchuk and Alan Bates, "Professor or Producer: The Two Faces of Academic Man," Social Forces 40:344-45 (May 1962).

16. Oliver Fulton and Martin Trow, "Research Activity in American Higher Education," Sociology of Education 37:31-46 (Winter 1974).

17. Richard A. Wanner, Lionel S. Lewis, and David I. Gregorio, "Research Productivity in Academia: A Comparative Study of the Sciences, Social Sciences, and Humanities," Sociology of Education 54:253 (Oct. 1981).

18. Everett C. Ladd, Jr., and Seymour M. Lipset, "How Professors Spend Their Time," The Chronicle of Higher Education 11:2 (Oct. 14, 1975).

19. For a bibliography of graduate school ratings, see the scores of references in Abraham Bookstein and Mary Biggs, "Rating Higher Education Programs: The Case of the 1986 White Survey," Library Quarterly 57:351-99 (Oct. 1987).

20. The principal studies are: Karl W. Deutsch, Andrei S. Markovits, and John Platt, eds., Advances in the Social Sciences, 1900-1980: What, Who, Where, How? (New York: Univ. Pr. of America, 1986); Daniel Bell, The Social Sciences since the Second World War (New Brunswick, N.J.: Transaction Books, 1982); and Robert McC. Adams, Neil J. Smelser, and Donald J. Treiman, eds., Behavioral and Social Science Research: A National Resource, (Washington, D.C.: National Academy Pr., 1982).

21. Fulton and Trow, "Research Activity," p.46, table 8.

22. For a summary of this literature, see Richard W. Woodman and Lyle F. Schoenfeldt, "Individual Differences in Creativity: An Interactionist Perspective," in Handbook of Creativity, eds. John A. Glover, Royce R. Ronning, and Cecil R. Reynolds (New York: Plenum, 1989), p.77-91. 
23. On the sacred spark thesis, see Jonathan R. Cole and Stephen Cole, Social Stratification in Science (Chicago: Univ. of Chicago Pr., 1973), p.114. See also Lowell L. Hargens, "Relations between Work Habits, Research Technologies, and Eminence in Science," Sociology of Work and Occupations 5:97-112 (Feb. 1978); and Alan Bryman, ed., Doing Research in Organizations (New York: Routledge, 1988).

24. Wilbert S. Ray, The Experimental Psychology of Original Thinking (New York: Macmillan, 1967), p.35, cited in James L. Adams, Conceptual Blockbusting: A Guide to Better Ideas (Reading, Mass.: Addison-Wesley, 1986), p.159. Some of the popular literature is quite good. See, for example, Denise Shekerjian, Uncommon Genius: How Great Ideas Are Born (New York: Viking, 1990).

25. Kathleen Garland and Galen E. Rike, "Scholarly Productivity of Faculty at ALA-Accredited Programs of Library and Information Science," Journal of Education for Library and Information Science 28:92 (Fall 1987).

26. Lane, "Characteristics Related to Productivity," p.158, cited in Pauline D. Wilson, "Factors Affecting Research Productivity," Journal of Education for Librarianship 20:16 (Summer 1979).

27. Herbert S. White and Karen Momenee, "Impact of the Increase in Library Doctorates," College \& Research Libraries 39:207-14 (May 1978), reprinted in Herbert S. White, ed., Librarians and the Awakening from Innocence (Boston: G. K. Hall, 1989), p.17.

28. White, Librarians, p.13-14.

29. Frank Clemente and Richard B. Sturgis, "Quality of Department of Doctoral Training and Research Productivity," Sociology of Education 47:295-96 (Spring 1974); and Frank Clemente, "Early Career Determinants of Research Productivity," American Journal of Sociology 79:416-17 (Sept. 1973).

30. Wanner, Lewis, and Gregorio, "Research Productivity," p.246.

31. Ibid., p.244-49.

32. Ronald Rayman and Frank Wm. Goudy, "Research and Publication Requirements in University Libraries," College \& Research Libraries 41:47 (Jan. 1980); and Thomas G. English, "Librarian Status in the Eighty-Nine U.S. Academic Institutions of the Association of Research Libraries," College \& Research Libraries 44:203-4 (May 1983).

33. DeBoer and Culotta, "The Academic Librarian," p.217; and Wilson, "Factors Affecting Research Productivity," p.16.

34. Budd and Seavey, "Characteristics of Journal Authorship," p.469.

35. Joyce Payne and Janet Wagner, "Librarians, Publication, and Tenure," College \& Research Libraries 45:138 (Mar. 1984); W. Bede Mitchell and L. Stanislav Swieszkowski, "Publication Requirements and Tenure Approval Rates: An Issue for Academic Librarians," College \& Research Libraries 46:252-53 (May 1985); and Rayman and Goudy, "Research and Publication," p.47.

36. Paula D. Watson, "Productivity of Scholary Articles by Academic Librarians and Library School Faculty," College \& Research Libraries 46:341 (July 1985).

37. Karen F. Smith and Gemma DeVinney, "Peer Review for Academic Librarians," The Journal of Academic Librarianship 10:90 (May 1984).

38. For a review of this literature, see DeBoer and Culotta, "The Academic Librarian," p.218.

39. Nancy J. Emmick, "Release Time for Professional Development: How Much for Research?" in Academic Libraries: Myths and Realities, ed. Suzanne C. Dodson and Gary L. Menges (Chicago: Assn. of College and Research Libraries, 1984), p.124-34, cited in DeBoer and Culotta, "The Academic Librarian," p.218.

40. Deborah E. Hunter and George D. Kuh, "The 'Write Wing': Characteristics of Prolific Contributors to the Higher Education Literature," Journal of Higher Education 58:452 (July-Aug. 1987); Charles K. West and William A. Hoerr, "Communication and Work Patterns among Productive Scholars in Psycho-Education Research," Human Relations 38:132 (Feb. 1985); and Wanner, Lewis, and Gregorio, "Research Productivity," p.246.

41. Robert Boice and Karin Johnson, "Perception and Practice of Writing for Publication by Faculty at a Doctoral-Granting University," Research in Higher Education 21:40 (1984).

42. Jerry Gaston, "The Reward System in British Science," American Sociological Review 35:726 (Aug. 1970).

43. Fulton and Trow, "Research Activity," p.61. 
44. Donald C. Pelz and Frank M. Andrews, Scientists in Organizations: Productive Climates for Research and Development (New York: Wiley, 1966), p.70, elaborated on in Hargens, "Relations between Work Habits," p.99.

45. Aaron Wildavsky, Craftways: On the Organization of Scholarly Writing (New Brunswick, N.J.: Transaction Publishers, 1989), p.3.

46. Robert Boice, "Experimental and Clinical Treatments of Writing Blocks," Journal of Consulting and Clinical Psychology 51:183-91 (1983); and Robert Boice, "Procrastination, Busyness, and Bingeing," Behavior Research and Therapy 27:605-11 (1989).

47. Robert Boice, Jordan M. Scepanski, and Wayne Wilson, "Librarians and Faculty Members: Coping with Pressures to Publish," College \& Research Libraries 48:500 (Nov. 1987). For an opposing viewpoint and Boice's reply, see Letters to the Editor, College $\mathcal{E}$ Research Libraries 50:99,106 (Jan. 1990).

48. Wanner, Lewis, and Gregorio, "Research Productivity," p.246.

49. White, Librarians, p.8.

50. David Kaser, "The Effect of the Revolution of 1969-1970 on University Library Administration," in Academic Libraries by the Year 2000: Essays Honoring Jerrold Orne, ed. Herbert Poole (New York: Bowker, 1977), p.69.

51. This kind of change in analytical approach is applicable to much of social science. See Clifford Geertz, "Blurred Genres-The Reconfiguration of Social Thought," American Scholar 49:165 (Spring 1980).

52. Mary Frank Fox, "The Transition from Dissertation Student to Published Scholar and Professional," in Scholarly Writing and Publishing: Issues, Problems, and Solutions, ed. Mary Frank Fox (Boulder, Colo.: Westview, 1985), p.6-7; Meltzer, "The Productivity of Social Scientists," p.27; Wanner, Lewis, and Gregorio, "Research Productivity," p.23940; Jerome G. Manis, "Some Academic Influences upon Publication Productivity," Social Forces 29:267-72 (Mar. 1951); Gary T. Marx, "Reflections on Academic Success and Failure," in Authors of Their Own Lives: Intellectual Autobiographies by Twenty American Sociologists, ed. Bennett M. Burger (Berkeley: Univ. of California Pr., 1990), p.270; and Barbara F. Reskin, "Scientific Productivity and the Reward Structure of Science," American Sociological Review 42:492 (June 1977).

53. Yoram Neumann and Edith Finaly-Neumann, "The Support-Stress Paradigm and Faculty Research Publication," Journal of Higher Education 61:565-80 (Sept.-Oct. 1990).

54. For surveys of research collaboration, see American Council of Learned Societies, "The ACLS Survey of Scholars: Views on Publications, Computers, Libraries," Scholarly Communication 5:6-7 (Summer 1986); Sue Stone, "Humanities Scholars: Information Needs and Uses," Journal of Documentation 38:294-95 (Dec. 1982); K. Subramanyam, "Bibliometric Studies of Research Collaboration: A Review," Journal of Information Science 6:33-38 (Mar. 1983); and Derek J. De Solla Price, Little Science, Big Science ... and Beyond (New York: Columbia Univ. Pr., 1986), p.160. On multiauthorship trends, see Paul Metz, "A Statistical Profile of College \& Research Libraries," College \& Research Libraries 50:45, table 4 (Jan. 1989). On the dynamics of collaborative relationships, see Mary Frank Fox and Catherine A. Faver, "The Process of Collaboration in Scholarly Research," Scholarly Publishing 13:327-39 (July 1982). 